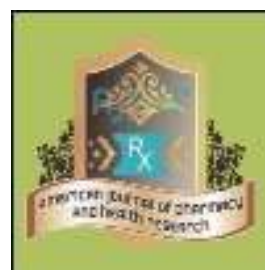

Research Article AMERICAN JOURNAL OF PHARMACY AND HEALTH RESEARCH www.ajphr.com 2019, Volume 7, Issue 3 ISSN: 2321-3647(online)

\title{
Study of Physico-Chemical Parameters of Different Water Samples
}

\author{
Shaziya Mohd Irfan Momin'1, Jayashree Sharad Thakre', Aarzoo ${ }^{1}$ Zoha Khan $^{1}$ \\ 1.Department of Chemistry, G.M.Momin Women's College, Bhiwandi
}

\begin{abstract}
The study was done to check the different physico-chemical parameters of different water samples of G.M Momin Women's College. The water samples were collected from different laboratories, canteen and R.O Filter of the college. The physico-chemical parameters which were investigated are turbidity and hardness. Water of good drinking quality is of basic importance to human physiology and man's continued existence depends very much on its availability. The concentration of most of the investigated parameters in the drinking and other water samples from G.M Momin Women's College were within the permissible limits of drinking water quality standards and guidelines.
\end{abstract}

Keywords: Water sample, Turbidity and Hardness. 


\section{INTRODUCTION}

Water dominates the surface of earth and is vital to life in our planet.It is a liquid which has remarkable anomalous behaviour. All living organism from lower to high need water to alive.

It has many chemical ,physical and biological properties. A clean and safe water is used in cooking, drinking, agriculture and industries etc.

But now a days due to pollution, water is polluted and decreases the quality of water and also affect the life quality of humans and animals. In polluted water many pathogens , microorganisms, bacteria are found which adversely affect the health of human and animal species. So there is a need to analyse the water and it's property content to remove the pollution from it and use as a clean water (1).

The hardness is due to presence of carbonates, bi-carbonate, chlorides and sulphates of calcium and magnesium in dissolved form. The hardness in potable water is determined using titration method. Total hardness in potable water is $9 \mathrm{mg} / \mathrm{L}$ as $\mathrm{CaCO}_{3}$, Calcium hardness is $4.7 \mathrm{mg} / \mathrm{L}$ and Magnesium hardness is $3.4 \mathrm{mg} / \mathrm{L}$.

Water is commonly classified as hard or soft depending on the type and amount of naturally occurring minerals and salts dissolved in it. The mineral content usually comprises of metal ion of calcium and magnesium in the form of their carbonates i.e calcium carbonate and magnesium carbonate but may includes several other component. Hardness is measured in milligrams / liter . The hardness is majorly classified into two i.e temporary and permanent.

- Temporary Hardness: This type of hardness can be eradicated simply by boiling . It occurs due to presence of dissolves calcium carbonate in water .

- Permanent Hardness: It is impossible to remove permanent hardness by boiling. It occurs due to presence of concentration of calcium and magnesium sulphates or chlorides in water. These becomes more soluble in water with increase in temperature $(2,3)$.

Turbidity is caused mostly by human activities in certain industries, such as mining and agriculture that causes movement of particles and gets mixed up with water.

Those can be mud, sand and other waste materials found in the changing environment. However, there is a certain particle that is a natural flora of water, especially seen in seawater, oceans and can be found in freshwater too this particle is known as Phytoplankton. Phytoplankton is a certain tiny plant that wanders or drifts to different bodies of water. This plankton is so small that it can only be seen using a microscope. This is also one of the reason of making water turbid. 
Measurement of turbidity of domestic water supplies is very important, as these supplies often undergo some type of cloudiness in the water. This can vary from a river full of mud and silt where it would be impossible to see through the water (high turbidity), to a spring water which appears to be completely clear (low turbidity).Turbidity can be caused by : silt, sand, mud ; bacteria, other germs and chemical precipitates. For example, during the rainy season when mud and silt are washed into rivers and streams, high turbidity can quickly block filters and stop them from working effectively. High turbidity will also fill tanks and pipes with mud and silt, and can damage valves and taps where chlorination of water is practiced, even quite low turbidity will prevent the chlorine killing the germs in the water efficiently $(4,5)$.

\section{MATERIALS AND METHOD}

Tap water sample was collected from the G.M.Momin Women's College, Bhiwandi from the Wet chemistry lab, Physical chemistry lab, Zoology lab, Botany lab, Canteen and RO filter.

Determination of Turbidity:

The 0.08505gram Barium Sulphate was taken in a volumetric flask. Distilled water up to the mark was added to dissolve Barium Sulphate. The $\mathrm{BaSO}_{4}$ solution of different concentration was pipetted out in a different volumetric flask. The turbidity reading of solution of different concentration was measured in the turbimeter as given below:

Table 1 : Turbidity Measurement

\begin{tabular}{ll}
\hline Concentration in ppm & Turbidity in NTU \\
\hline 5 & 23 \\
10 & 38 \\
15 & 72 \\
20 & 84 \\
25 & 94 \\
\hline
\end{tabular}

\section{Determination of Hardness:}

Water sample was taken in the conical flask, $5 \mathrm{~cm}^{3}$ of buffer solution and a pinch of Eriochrome Black- $\mathrm{T}$ indicator was added. The solution was titrated against EDTA and the amount of hardness was determined.

RESULTS AND DISCUSSION:

Turbidity was measured by using Turbimeter.

Table 2 : Turbidity in NTU

\begin{tabular}{ll}
\hline Water Sample & Turbidity in NTU \\
\hline Wet chemistry lab & 6.4 \\
Physical chemistry lab & 0.5 \\
Zoology lab & 2.7 \\
\hline
\end{tabular}




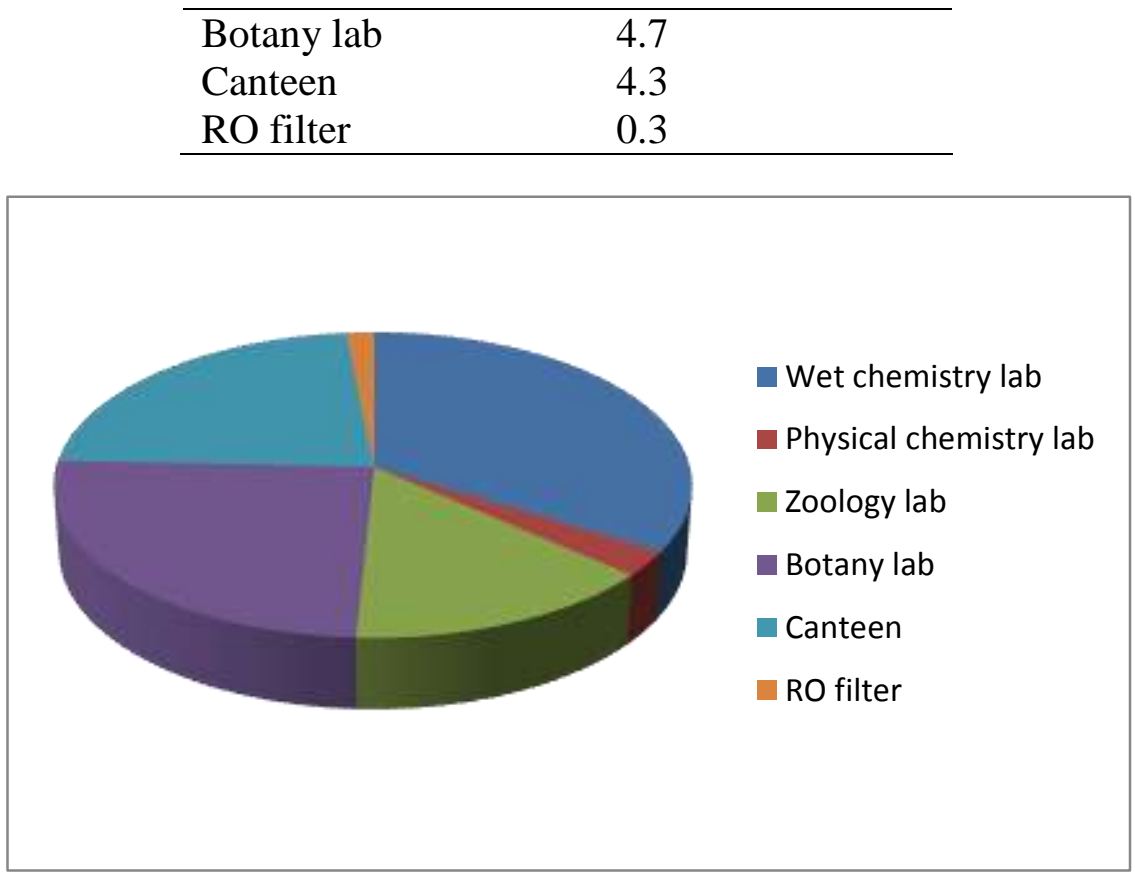

Figure 1 : Turbidity of different water sample

Table 3: Hardness:

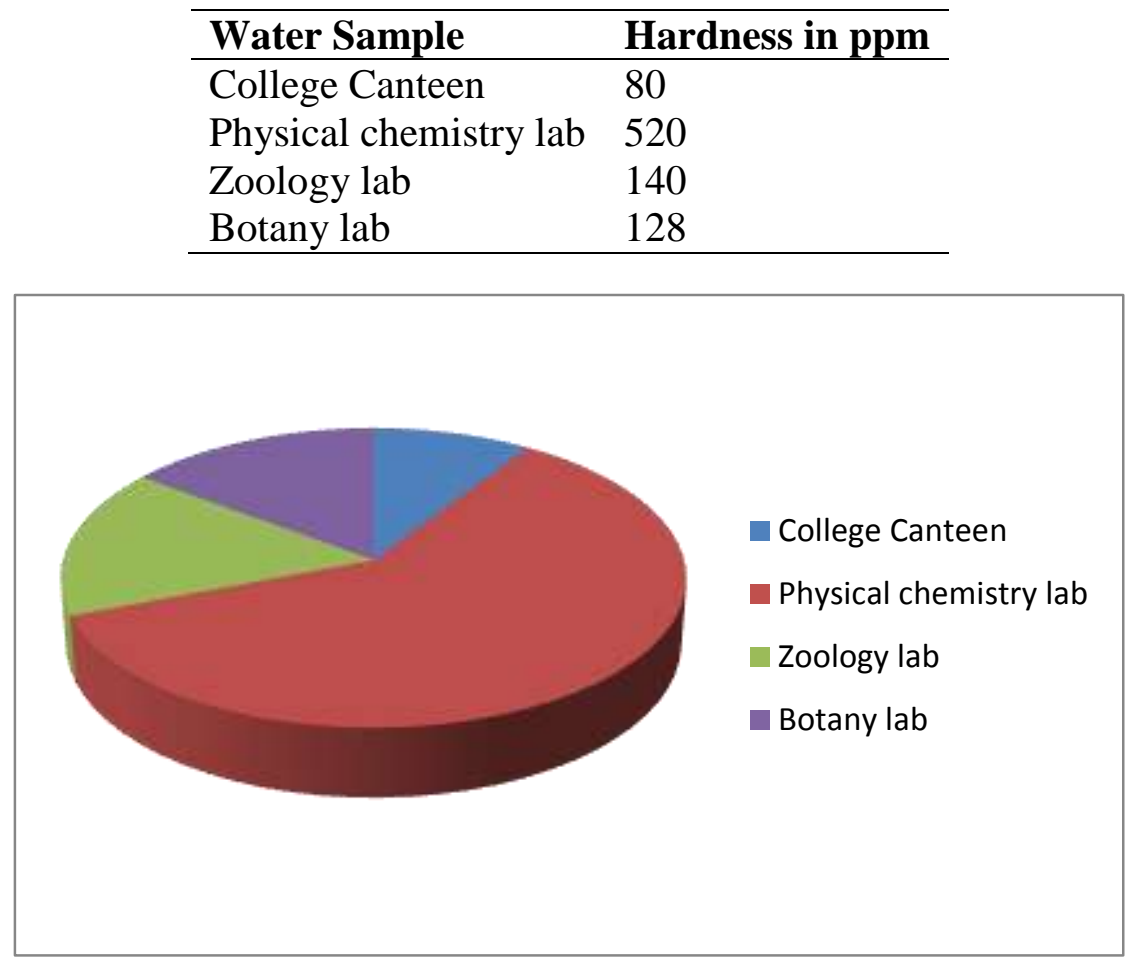

Figure 2 : Hardness of different water sample

\section{CONCLUSION:}

Turbidity is a cloudiness or haziness of a liquid( water) caused by large number of individual particles that generally invisible to nacked eye .WHO organization established that the drinking water should not have turbidity more than 1.5 NTU . Turbidity is a key test of the water quality. 
Physical chemistry lab water and RO filter water shows Turbidity less than 1.5NTU and rest of the other sample possess the Turbidity greater than 1.5NTU.

Hardness of all water samples are less than 500ppm and 300ppm except the physical chemistry lab water where hardness value is 520ppm greater than the standard prescribed by standard body like WHO (500ppm) and BIS (300ppm) $(3,4)$.

\section{ACKNOWLEDGMENT:}

Authors are very thankful to Star College Scheme, DBT, Ministry of Science and Technology, Government of India for sanctioning the amount for the research project.

\section{REFERENCES:}

1. Nature, Environment and Pollution technology, Volume No.10 March 2011, Page No.156, Management of Drinking Water Quality at Malivya National Institute of Technology, Jaipur, A Case Study-Physical Chemical Quality of Drinking Water

2. Journal of American Chemical Society, Vol No. 21, page no 516 -517

3. http://www.water.research.ref/watqualindex/index.him

4. https://www.who.int/water_sanitation_health/hygiene/emergencies/fs2_33.pdf

5. Physico-Chemical Analysis of Drinking Water Quality of Arbaminch Town, Journal of Environmental \& Analytical Toxicology

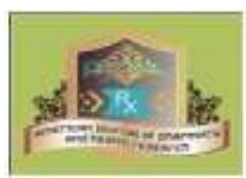

AJPHR is

Peer-reviewed

monthly

Rapid publication

Submit your next manuscript at editor@ajphr.com / editor.ajphr@gmail.com 